\title{
The Tenets of The Mah Meri Oral Tradition, Life Issues and Challenges in Pulau Carey, Selangor
}

\section{Mohd Haikal Zuhairi, Mohd Roslan Rosnon \& Asnarulkhadi Abu Samah}

To Link this Article: http://dx.doi.org/10.6007/IJARBSS/v11-i12/11789

DOI:10.6007/IJARBSS/v11-i12/11789

Received: 10 October 2021, Revised: 13 November 2021, Accepted: 28 November 2021

Published Online: 16 December 2021

In-Text Citation: (Zuhairi et al., 2021)

To Cite this Article: Zuhairi, M. H., Rosnon, M. R., \& Samah, A. A. (2021). The Tenets of The Mah Meri Oral Tradition, Life Issues and Challenges in Pulau Carey, Selangor. International Journal of Academic Research in Business and Social Sciences, 11(12), 429-439.

\section{Copyright: @ 2021 The Author(s)}

Published by Human Resource Management Academic Research Society (www.hrmars.com)

This article is published under the Creative Commons Attribution (CC BY 4.0) license. Anyone may reproduce, distribute, translate and create derivative works of this article (for both commercial and non0-commercial purposes), subject to full attribution to the original publication and authors. The full terms of this license may be seen at: http://creativecommons.org/licences/by/4.0/legalcode

\section{Vol. 11, No. 12, 2021, Pg. $429-439$}

Full Terms \& Conditions of access and use can be found at http://hrmars.com/index.php/pages/detail/publication-ethics 


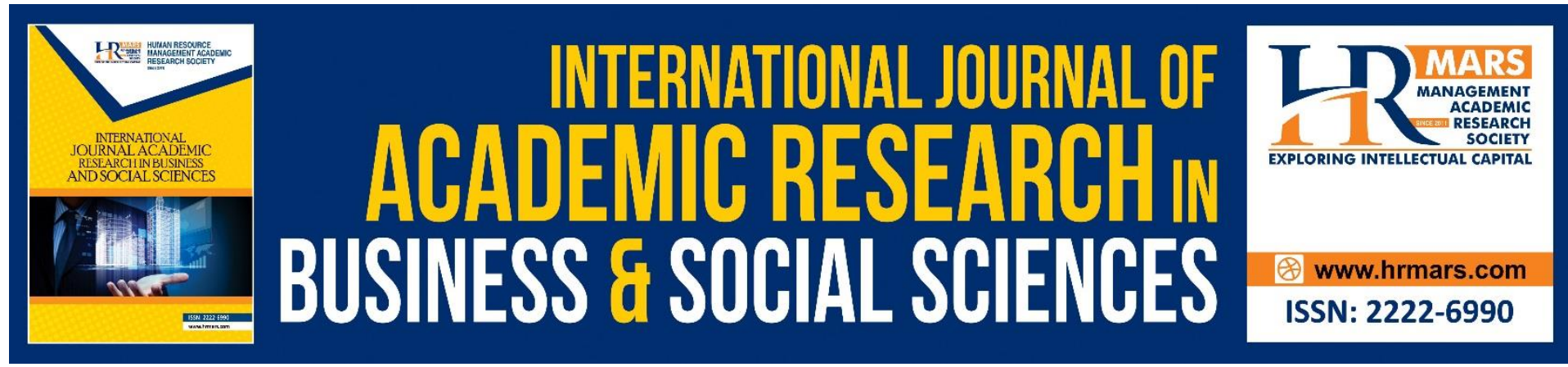

\title{
The Tenets of The Mah Meri Oral Tradition, Life Issues and Challenges in Pulau Carey, Selangor
}

\author{
Mohd Haikal Zuhairi ${ }^{1}$, Mohd Roslan Rosnon ${ }^{1,2}$ \& Asnarulkhadi \\ Abu Samah ${ }^{1}$ \\ ${ }^{1}$ Department of Social \& Development Sciences, Faculty of Human Ecology \\ Universiti Putra Malaysia, ${ }^{2}$ Malaysian Research Institute on Ageing (MyAgeing), Universiti \\ Putra Malaysia, Serdang \\ Email: roslan_rosnon@upm.edu.my
}

\begin{abstract}
For many years, the government and many other benefactors have done initiatives to improve the community, however the results were not satisfactory. Therefore, this research will focus to understand the tenets of the Mah Meri oral tradition and to explore the Mah Meri's experience, thoughts and feedbacks to the current issues and challenges. This research has used qualitative method with narrative research design. In-depth interviews were conducted on seven informants and later were analysed thematically. The finding shows that, there are 4 main major concepts that are revolved around the Mah Meri's oral tradition which are: 1) Kemali; 2) Tulah; 3) Bentan; and 4) Maruk. The findings also found that, there are significant number of issues and challenges within the Mah Meri community. Covering the aspect of economics, politics, social, education, culture and belief system, and health and well-being, there are trend shown on how modernization has changed and affected the Mah Meri people's lives. Thus, this research is important not only to navigate deeper and validate on how close our Orang Asli with nature and their belief system, but also a part of efforts in contributing a scholarly review on the Orang Asli oral tradition studies in Malaysia.
\end{abstract}

Keywords: Orang Asli, Mah Meri, Belief System, Oral Tradition, Values

\section{Introduction}

In Malaysia, the Indigenous people are also known as 'Orang Asli' which is a Malay phrase for 'Aborigines' or 'Indigenous' and it is the official term that been used in Malaysia (Rosnon, 2014; Werner, 1997). In fact, Malaysia has many types of indigenous people. They are also not the Malays, but given 'Bumiputera' status. The word 'Bumiputera' is derived from the Sanskrit which carries the literal meaning of 'son of the land' or 'son of the soil' (Sornarojah, 2010 as cited in Anwar et al., 2013; Rosnon, 2016). However, the term 'Orang Asli' is interchangeable with the term 'Indigenous' or 'Aborigines' that were widely used by the British colonial admiration (Gomes, 2014; Rosnon, 2016). Gomes (2004) argued further that the exact definition of 'Orang Asli' refers to the indigenous people of Peninsular Malaysia only, who are not Malay-Muslim. Together with indigenous peoples of Sabah and Sarawak which are not called as 'Orang Asli', and the Malays, these peoples are the groups that known 
and recognized as 'Bumiputera', which makes up 65.1 percent from the total Malaysia population (see table 1). From the population, the portion the 'Orang Asli' which are the 'Indigenous Peoples' of Peninsular Malaysia is only from 0.5 to 1 percent, thus make them the minority group of Malaysia's 'Bumiputera'.

Table 1: Categories of Bumiputera

\begin{tabular}{|c|c|c|c|}
\hline \multicolumn{4}{|c|}{ Bumiputera of Malaysia } \\
\hline - Orang Asli & - Malays & $\begin{array}{c}\text { - Indigenous } \\
\text { peoples of } \\
\text { Sabah }\end{array}$ & $\begin{array}{c}\text { - Indigenous } \\
\text { peoples of } \\
\text { Sarawak }\end{array}$ \\
\hline
\end{tabular}

In peninsular Malaysia, the Orang Asli is mainly separated into three major tribal groups which are the Semang (Negrito), the Senoi and the Proto Malay (see table 2). In total, there are 18 ethnics under these three major tribal groups and each of the ethnics have their own features such as language and culture that distinguishes themselves differently from the others (Masron et al., 2013; Sarjit \& Rosnon, 2018).

Table 2: Ethnics of Orang Asli in Peninsular Malaysia

\begin{tabular}{lll}
\hline Semang (Negrito) & \multicolumn{1}{c}{ The Orang Asli } & \\
- Bateq & - Che Wong & Proto Malay \\
- Jahai & - Jahut & - Jakun \\
- Kensiu & - Mah Meri & - Orang Kanaq \\
- Kintak & - Semai & - Orang Kuala \\
- Lanoh & - Semoq Beri & - Semelai \\
- Mendriq & - Temiar & - Temuan \\
\hline
\end{tabular}

Masron, Masami and Ismail (2013) made further claim that in terms of politic and economic, the natives of Sabah and Sarawak are actually in a better position to be compared with the peninsular Orang Asli. When it comes to authoritative and government body, the JAKOA which stands for Jabatan Kemajuan Orang Asli or The Department of Orang Asli Development under Malaysian Ministry of Rural Development is the government agency that entrusted to oversee the Orang Asli's affairs (Rosnon \& Abu Talib, 2019; Rosnon \& Sara, 2015).

Therefore, Orang Asli is used to describe the Aboriginal inhabitants of Peninsular Malaysia who have their own culture, language, faith and lifestyle. The Orang Asli are not a homogeneous ethnic minority (Gomes, 2004a; William-Hunt, 1998). They are a heterogeneous people with socio-cultural differences between each tribe. For example, according to Zalizan et al (2009), Orang Asli community groups in Peninsular Malaysia have their own dialects and languages across their tribes. The Semelai dialect is part of the AustroAsian language family, while the proto-Malay groups, are part of the Austronesian family (Zalizan et al., 2009, pp. 5-6). Orang Asli languages are generally only understood amongst themselves. Modernization has, to some extent, affected the lives of indigenous peoples and exposed them to the current development (Rosnon, 2010; Rosnon et al., 2019). 


\section{Literature Reviews \\ The Mah Meri People}

Mah Meri people is a sub-ethnic under the Senoi group. Almost all of the Mah Meri people live along the coastal region of the west part of Selangor, from Sungai Pelek up to Pulau Carey. Due to this uniqueness, Roland Werner preserved and documented the stories of Mah Meri people in his works as well. In additional, the name of the island which is Pulau Carey may come from the reference to Jugraland and Carey Island Co.Ltd, which was a Scottish-based company that initially started their coconut plantation there in late 1890's (Rahim, 2007). Hae (2007) further elaborated that there are five main Mah Meri villages (see table 3 ) on Pulau Carey which are:

Table 3: Mah Meri villages on Pulau Carey

\begin{tabular}{ccccc}
\hline \multicolumn{4}{c}{ Mah Meri villages on Pulau Carey } \\
Kampung & Kampung & Kampung & Kampung Kepau & Kampung \\
Sungai Bumbun & Sungai Judah & Sungai Kurau & Laut & Rambai \\
\hline
\end{tabular}

Demographically, Hae (2007) made further explanation on describing that the majority of the Mah Meri people still belief the animistic, superstitious and naturalistic which believing in their Moyang, even though small number have converted to Islam or Christianity. Literally, the phrase Moyang means ancestor in Bahasa Malaysia or Malay Language. However, for Mah Meri people, Moyang carries meaning for both their ancestors and other spiritual beings, or spirits. In fact, they believe that mortals and humans live on the 'Sixth World' or also known as Ti' Enam(Zuhairi, Rosnon \& Shaari, 2020). Meanwhile, all of the Moyang or their ancestors, and those good spirits and spiritual beings reside in the 'Seventh World' or 'Overworld' which is known as Ti' Tujoh. Below are the five layers of the Underworld, which the realms that are filled with bad spirits and spiritual beings, hantu or ghosts, diseases, and poisonous creatures (Zuhairi, Rosnon \& Shaari, 2020). The Mah Meri people can be classified as a society that practices animism that believes and depends on the forest and the sea for survival and spiritual purposes (Wardhana et al., 2014).

It is found that Werner's Mah-Meri (published 1997), first volume from the Culture of Healing in Malaysia: Aborigines and Indigenous Peoples Culture of Healing Sub-Series documented the relationship between the wooden carvings of the Mah-Meri people with their belief and folklore in hope "...to help the understanding, in other regions of the world, of one part of the great variety of the Malaysian cultural heritage". Hae (2007) further described on how the Mah Meri people actually more familiar conversing in Malay Language nowadays which resulted from the formal schoolings. Yet, the mother tongue language which is Bersisi' language has still been practiced when conversing among them. Based on Werner (1997), the term 'Mah-Meri' carries a literal meaning of 'forest people'. The culture of Mah-Meri people also seems more of Proto-Malay group despite they are under category of Senoi. Werner also stated that Pulau Carey can be considered as the main focus of the Mah-Meri population. Due to their popularity as well, nowadays the Mah-Meri people at Pulau Carey also have their own Mah-Meri Cultural Village to oversee any tourism affairs and also as a one stop centre for outsiders to reach the community.

Located near to the Port Klang and Banting, the Mah -Meri people at Pulau Carey are widely and internationally recognized especially due to their unique wood carvings. Maznah (2017) and Mokhtar (2014) stated that each of the wood carvings are inspired by dreams had by the 
carvers. They believe that the spirits, deities, or their ancestors would come into their dreams to tell or warn about something. Thus, the dreams are personified into the carvings as a form of respect. Occasionally, the wooden carvings which are either wooden statues or wooden masks would be used in their rituals and prayer or culture ceremonies. However, the carving practices are only be done by menfolk in Kampung Sungai Bombon and not by other Mah Meri folk from other kampung or villages (Hae,2007). Wooden carving practices are only some of the belief systems of the Mah Meri people. Since the people belief in animism, thus they rely heavily on oral tradition such as folklore, legends and myths, and all the oral stories that are passed down from generation to generation. These stories are important for the people as some the essences and the tenets of the stories not only contribute to the people's belief system, but also to their life concept and principles, which are just as same as the other Orang Asli sub-groups too. When it comes to the language, the Mah Meri people in Pulau Carey will use Malay language or Bahasa Melayu instead of their native language which is Besisi language, due to the familiarity and exposure they got from modernization (Majin, Azman \& Jailani, 2016).

\section{Methodology}

This narrative research design that aimed to understand the Mah Meri's oral tradition and to explore the experience, thoughts and feedbacks on the current issues and challenges. This research has used qualitative research in depth-interview data collection technique by asking specific designed questions to the selected Mah Meri people with snowball sampling technique that have met the interview criteria:

i. must be a Mah Meri people where one of the parents is the original Mah Meri people;

ii. resided in Pulau Carey, Selangor for at least 10 years; and

iii. have knowledge of oral tradition/folklore.

The structure of the interview questions is based on the selective focused topics, covering the following aspects:

i. The tenets of the Mah Meri oral tradition/folklore

ii. Economics (issues and challenges)

iii. Politics (issues and challenges)

iv. Social (issues and challenges)

v. Education (issues and challenges)

vi. Culture and belief system

vii. Health and well-being (issues and challenges)

There were seven informants that met the criteria been acquired and interviewed. Six out of seven respondents are animist while one is a Muslim. Some of the interviewed informants were Tok Batin, Chief of the Village, community leaders and elderly. The interview sessions were undergone from January 2021 to March 2021, and the audios of the interview session are recorded, which later on are transcribed and analysed. The data has been analysed and synthesised in narrative approach based on the objectives research.

\section{Findings and Discussions}

\section{The tenets of the Mah Meri Oral Tradition}

Based on Welner (1974), there are over hundreds of Mah Meri folklore or oral traditions recorded, where each of the story revolve either around the story of Moyang or spirit, or just 
common folktales with learning and messages. Karim (1981) later on dived deeper in Mah Meri life experience and in her significant work; Ma'Betise' Concepts of Living Things, she has concluded the Mah Meri's life concepts which are also the tenets of the Mah Meri oral tradition or folklores. There are two identified and recorded tenets which are 'Tulah' and "Kemali". However, during the interview session, it is found that there are 2 more tenets of concepts which are 'Bentan' and 'Maruk', that are familiar and believed by the Mah Meri people.

Table 4: The discovery of the Mah Meri's oral tradition and live being tenets

\begin{tabular}{|c|c|c|}
\hline $\begin{array}{l}\text { Tenets / } \\
\text { concepts }\end{array}$ & Discovery & $\begin{array}{l}\text { Familiarity ranking ( } 1 \text { for the } \\
\text { most familiar with, and } 5 \text { for } \\
\text { the least familiar with) }\end{array}$ \\
\hline ‘Tulah’ & $\begin{array}{c}\text { Ma' Bestise's Concepts of Living Things } \\
\text { (Wazir-Jahan 1981) }\end{array}$ & 2 \\
\hline 'Kemali' & $\begin{array}{c}\text { Ma' Bestise's Concepts of Living Things } \\
\text { (Wazir-Jahan 1981) }\end{array}$ & 3 \\
\hline 'Bentan' & $\begin{array}{l}\text { During these research interviews } \\
\text { execution (2021) }\end{array}$ & 1 \\
\hline ‘Maruk’ & $\begin{array}{l}\text { During these research interviews } \\
\text { execution (2021) }\end{array}$ & 4 \\
\hline
\end{tabular}

The definitions and the informant's understanding towards these four concepts are drawn from the analysed interview data. Based on the ranking (see table 4), the concept of 'Bentan' is ranked as the most familiar tenet for the Mah Meri people since all the seven informants able to define it's definition and the examples of it. 'Bentan' is known and define as bad consequences or bad things that will happen after breach of taboo. Most often than not, the taboos are related with health, healing and spirituality where one is under recovery or healing treatment and need to undergo certain taboo or restriction, such as must not eat or consume bird eye chili or locally known as cili api, or the scientific name is 'capsicum annuum' while under pantang or taboo, a part of the healing and treatment process. "Bentan will happen if we did not follow what our Tok Batin has told us, such as not to eat cili api for 3 days. But if we still eat it, then we will get bentan. So once we get bentan, the situation will be harder, and even Tok Batin also won't help us anymore" Informant 1. Otherwise, the sickness will only get worse which is the 'Bentan', and she or he will be unable to be healed or treated and may lead to death. All of the seven informants articulated the definition and the examples of 'Bentan'.

The second one is 'Tulah' which carries meaning of something bad or bad consequences that will happen if one disrespects or harms the other human being, particularly someone who has higher rank than you, not limited by age. For an example by being rude or disrespect to someone who has the 'uncle' rank among the family or community, even he actually is younger by age, Tulah will happen and occur. "Tulah is something bad that will happen to us, can be something like an accident, or can be anything, if we did not follow whatever our parents, or our ancestors, or someone older than us have told or advised us" Informant 2. The informants were not able to give specific of definite examples of 'Tulah' however they do have strong belief in this tenet and agreed with the generalised definition of it; the bad things or 
curses may occur on you, or health-wise, or economics-wise such as unable to get anything from hunting or fishing.

The third one is 'Kemali', which is similar with 'Tulah' however the bad consequences or something bad will happen if one disrespects or harms non-human being objects. These objects are not limited to any specific type, as it may be as simple as simple household items or utensils that are commonly used, such as pestle or locally known as 'batu lesung', or knife sharpening stone that is commonly known as 'batu asah pisau'. "There are many forms of 'kemali', and of the examples is about using a 'batu lesung'. We need to use it delicately and make sure that we don't break it. If it broke while we using it, anything bad may happen to us, or our family members" informant 3. One must use these utensils properly and carefully, as if one drops it and makes it break into halves, something bad will happen, be it sickness, or no catch from hunting or fishing.

The last one is 'Maruk. Out of seven informants, six able to define the meaning and definition of 'Maruk' while one claimed that never heard or known this concept. 'Maruk' is signs or omens of bad things that will happen soon, usually it is specific on signing someone is going to pass away or die, be it close relative family members, villagers, or even someone from another village. "Maruk, what my late grandma had told me before, 'Maruk' is a sign that someone is going to pass away. These signs usually in a form of any uncommon behaviour, may be done by anyone? It's pretty random. For an example, if a husband never cooked before, and one day he went to a kitchen and started cooking, it's pretty abnormal, and this could be a sign that somehow, somewhere, someone is going to pass away. Could be any of family members, or any of villagers" Informant 4. The six informants however unable to really specifically the examples of 'Maruk', yet the informants explained in general that it could be some uncommon behaviours shown or demonstrated by random people that may draw attention ; that someone else and not the doer will pass away. Another random example given by the informant is a scenario where a husband never cooked or even interest to clean the kitchen, however suddenly he cooks a lot which is uncommon and out ordinary; this is a sign that someone else a random people, be it a friend, a close relative member, another village or even someone random from another village will pass away.

\section{The Issues and the Challenges}

Moving on, the informants were asked related questions about 5 different related topics of their life issues and challenges; economics, politics, social, education, health and well-being. Each of the sections covering specific question on comparison of previous or the old mechanism versus the present, any reasons behind the changes occurred, what are the issues and challenges present within it, and if the Mah Meri people may obviously relate any of the four tenets with the discussed topic.

For the economics section, the informants agreed and claimed that there were significant changes when it comes to comparing the old and the current economic activities. "In the old days, the Orang Asli here would do traditional economic activities such as fishing or harvesting of forest products. But now, the economic opportunities are more and better with modern economic activities" Informant 1 . In the old days, the Mah Meri people mainly involved with traditional economic activities such as catching seafoods, mainly on by fishing, followed by traditional farming such as paddy in a small scale or local fruits. Since fishing used to be their 
main economic activities, it's not doable nowadays for it to be the primary activity again due to the lesser fish population resulted from overfishing, and uncontrolled modern fishing techniques used by the modern fishermen. It is seen that more of the Mah Meri people in Pulay Carey started to accept modern and outside economic activities such as contract working with companies, including becoming cleaners, or general workers for the nearest oil palm plantation.

When it comes to leadership and politics discussion, interview outcome shows suggest that 'Tok Batin' used to be most-respected community leader among the people and did not only govern cultural affairs, but also including general management of the village. "Back then, the villagers respected Tok Batin more and greater; he would be in charge just like the Village Chief, even his responsibility and rank is like a Sultan, for us; he would know anything, and would look after his subordinates and villagers" Informant 2. However, modern leadership and politic structure, the presence of JAKOA or 'Jabatan Kemajuan Orang Asli' has helped a lot in terms of systemizing the village leadership and management structure. In modern context, an Orang Asli village may also have a special committee called JKKKOA or 'Jawatankuasa Kemajuan dan Keselamatan Kampung Orang Asli', with the head committee that plays role like a village chief, to oversee the village management. Nevertheless, 'Tok Batin' still play his roles however is now focusing more on traditional and cultural related affairs, that are also including the Orang Asli's belief system such as traditional or healing ceremonies or rituals.

The informants were also asked about the social system and the issues and challenges that may occur. As one of the Orang Asli sub-groups in Malaysia, most of the informants agreed that the old way of social system and mechanism of the villages were better strengthened and united compared to the presents. "People in the old days, they had better and more strengthened unity compared to us today. For examples, where there were ceremonies or weddings, everyone would come and help preparing the events, like weaving the 'bunga anyam' all together. But now, I can see that this spirit is no longer as strong as before" Informant 3. During the old time, almost all of decisions or activities were done together and collectively, however in current and modern generation, it is seeming that these features started to disappear as modern generations and the youngsters are seemed more 'individualist' and show least interest to really doing things collectively and unitedly just like the old generations. When it comes to social issues, the informants agreed that some of the modernization elements such as smart devices, and internet may change the younger generation's behaviours and way of thinking; as they seem to interested more with entertainment than education and academic. "Younger generation now like to play their phones all the time, especially now they can explore mobile apps and mobile games. Even some of them don't know how to read Malay language or English language, interestingly they still know which button to press, how to choose and search on YouTube to watch videos" Informant 4. This effect goes beyond the younger generation too as the older generation like the parents are also seems to be addicted with smart devices and internet entertainment like games and YouTube, and show minimal interest in proper parenting, compared to the old time.

This linked and associated with the issues and challenges in education. While most of the informants claimed that the current education system may seems harder compared to the 
last time, however it does functions better with better improvements, such as facilities, teachers' roles and initiatives to go beyond in educating the students, even including the parents under KEDAP or Kelas Dewasa Ibu Bapa Orang Asli Dan Penan, but the main backbone behind this are the parents themselves. "Back then, I feel the education and schooling subjects were easier compared to today's" Informant 7. As mentioned earlier, it is agreed that the parents may perceive that education has less and minimal importance for their children compared to encouraging them to get working in since the young age and bring in more hard money: which has direct benefits to the family well-being. "In fact, parents here feel that it is better for their children to learn being independent by finding money at the young age, to help and support the family economy. They don't realize the importance of education in a long run" Informant 5. Thus, lack of parents' supports in children's academic and education is so far regarded as the main issue and challenge in bringing the Mah Meri children's education and performance into the higher level.

For the culture and belief system part, the informants agreed that the Mah Meri people still strongly believe in their traditional culture values and belief system. "I think, we are still good and strongly believe in our belief and culture, we still do, follow and practices the practices and rituals" Informant 5. In fact, in their answers, they have stressed this multiple times by also adding that the culture and belief system aspect are regarded as the most important aspects in their lives. Even small numbers of the Mah Meri people have converted into others religion like Islam and Christianity, it does not affect the relationship between and among them, with the other Mah Meri people. Nevertheless, the Mah Meri people do concern about the outsiders who may take advantage on them for religion-related agenda; such as any missionaries or dakwah based programmes are specifically done, to get more and more Orang Asli converted. As the Mah Meri people do not oppose any of the community members that chose to convert, but these should not pressure or encourage the people to do so, as it is better let it be by their own wills.

Lastly is the health and well-being aspects. Most of the informants agreed on the importance of the traditional healing rituals or medicines. "Back then, the mortality and sickness rate were lower because we had tok batin and shamans. The Orang Asli are strongly believing in traditional healing skills and knowledges of the tok batin and shamans. But now, there are lesser tok batin and shamans, so we started depending more on modern treatment and health system" Informant 6 . In the old days, the 'Tok Batin' was the one that mainly oversaw these affairs, however due to modernisation such as better paved roads, initiatives by modern hospitals to come to the villages every month, and the conveniency of modern medicines, more of the Mah Meri people are comfortable with depending on modern health system instead of the traditional one that involved traditional herbs or leaves that may hard to be acquired nowadays, and even with stricter taboo with traditional mantras or ceremonies/rituals involved while undergoing traditional healing and recovering treatment. Thus, the dependency on the traditional health system among the contemporary is getting lesser as the modern health system and benefits are emerging more and more.

\section{Conclusion}

In conclusion, it is found that there are significant number of issues and challenges found within the Mah Meri community, drawn from the selected topics and aspects analysed throughout this research. Covering the aspect of economics, politics, social, education, 
culture and belief system, and health and well-being, there are trend shown on how modernization has changed and affected the Mah Meri people's lives; which in certain arguments it does bring benefits and values. However, these come with prices as there are also some cons, issues and challenges resulted from modernisation, which also affect the people's lives. Interestingly, the informants were also asked about their familiarity towards the four tenets identified within the Mah Meri oral tradition. Yet, the answers obtained shown that the familiarity level is just around satisfactory. As the informants answered that they have heard or 'familiar' with the concepts, yet they unable to convey the actual and specific definitions and examples of almost half of the tenets discussed. Onwards, the informants were also asked about the relationship between these tenets with the elements asked about their lifestyle, however the informant also unable to draw any significant or obvious relationship among these two. Thus, this suggests that the tenets of the Mah Meri oral tradition may no longer significantly affect and influence the people's life, which is now seen are most likely changed and affected by the modernization elements discussed. Thus, this research may allow the stakeholders to position their proposed development plans and policies be aligned and accordance to the Mah Meri people's needs.

\section{Acknowledgment}

The authors are thankful to the Ministry of Higher Education Malaysia for the award of Fundamental Research Grant Scheme - FRGS/1/2019/SS06/UPM/02/4 for the financial support and those were involved in this research. Some of the data and contents in this paper were excerpted from the research of Pembentukan Pengukuran dan Kerangka Model Bersepadu bagi Kesejahteraan Warga Emas Orang Asli di Semenanjung Malaysia (Development of Measurement and Integrated Model Framework for the Well-Being of Orang Asli Elderly in Peninsular Malaysia).

\section{References}

Anwar, O. M., Hussain@Hashim, W. A. F., Abu Bakar, J., \& Zakaria, Z. (2013). Legitimacy of the Malays as the Sons of the Soil. Journal of Asian Social Science, 9(1), 74-84.

Masron, T., Masami, F., \& Ismail, N. (2013). Orang Asli in Peninsular Malaysia: Population, Spatial Distribution and Socio-Economic Condition. Journal of Ritsumeikan Social Sciences and Humanities, 6, 75-115.

Gomes, A. G. (2004a). Looking for Money: Capitalism and Modernity in an Orang Asli Village. Melbourne: COAC, Kuala Lumpur and Trans Pacific Press.

Gomes, A. G. (2004b). The Orang Asli of Malaysia. Netherlands: IIAS News Letter

Rahim, R. (2007). Chita' Hae Culture, Crafts and Customs of the Hma' Meri in Kampung Sungai Bumbon, Pulau Carey. Subang Jaya: Center for Orang Asli Concerns.

Rosnon, M. R. (2010). Penggunaan Barangan dan Perkhidmatan Sebagai Petunjuk Pembangunan Komuniti Orang Asli Di Daerah Jelebu, Negeri Sembilan. (Master Master), Universiti Putra Malaysia, Serdang.

Rosnon, M. R. (2014). Challenges on the Orang Asli's Rights in Mainstream Education in Malaysia: An Overview. Malaysian Journal on Human Rights, 57-72.

Rosnon, M. R. (2016). Indigenous education policies in Malaysia and Australia: a study of the recognition of indigenous rights and self-determination. (PhD), University of South Australia, Adelaide South Australia. 
Rosnon, M. R., \& Abu Talib, M. (2019). Indigenous Education Rights: The Malaysian Case. International Journal of Academic Research in Business and Social Sciences, 9(10), 149167.

Rosnon, M. R., \& Sara, C. (2015). Discourse Of Indigenous Education Policy: The Malaysian Case. International Journal for Innovation Education and Research, 3(10), 126-140.

Rosnon, M. R., Sarjit, S. G., Azahari, S. Z. B., Fahada, N. A. W. A. R., \& Danial, A. H. G. (2019). Petunjuk pembangunan komuniti orang Asli: Suatu analisis penggunaan barangan dan perkhidmatan. GEOGRAFIA Malaysian Journal of Society and Space, 15(1), 132-146.

Sarjit, S. G., \& Rosnon, M. R. (2018). Pembangunan Kontemporari Orang Asli. Serdang: Penerbit Universiti Putra Malaysia

Wardhana, F. S., Yuhan, X., \& Qian, C. (2014). A Study of Cultural Identity, Cultural Heritage and Tourism Development in Mah Meri Community Cultural Village, Carey Island, Selangor, Malaysia.

Wazir-Jahan, B. K. (1981). Ma' Betisek Concept of Living Things. (PhD), London School of Economics, New Jersey.

Werner, R. (1997). Mah Meri. Kuala Lumpur: University of Malaya Press.

Zalizan, M. J., Abdul Razak, A., \& Rafaai, A. (2009). Perspektif Historiografi Masyarakat Orang Asli di Semenanjung Malaysia. In A. Abdul Razak \& M. J. Zalizan (Eds.), Masyarakat Orang Asli: Perspektif pendidikan dan sosiobudaya. (pp. 1-18). Bangi: UKM.

Zuhairi, M. H., Rosnon, M. R., \& Shaari, J. (2020). A Systematic Review on The Mah Meri People in Malaysia. International Journal of Academic Research in Business and Social Sciences, 10(16), 73-95. 